\title{
Connectivity restoration of floodplain lakes: an assessment based on macroinvertebrate communities
}

\author{
Krystian Obolewski • Katarzyna Glińska-Lewczuk • \\ Małgorzata Ożgo • Aleksander Astel
}

Received: 24 February 2015/Revised: 19 September 2015/Accepted: 3 October 2015/Published online: 14 October 2015

(C) The Author(s) 2015. This article is published with open access at Springerlink.com

\begin{abstract}
Successful rehabilitation programmes of river-floodplain systems require understanding of environmental impacts of restoring hydrological connectivity. The present study is based on a field experiment carried out between 2008 and 2013 in a floodplain of a lowland river in northern Poland, in which two oxbow lakes isolated in the 1920s were reconnected to the main river channel. Water and macroinvertebrate samples were collected three to four times a year from six sites $(n=114)$. After reconnection, water quality in the oxbow lakes improved and diversity and abundance of macrozoobenthos
\end{abstract}

Guest editors: Pierluigi Viaroli, Marco Bartoli \& Jan Vymazal / Wetlands Biodiversity and Processes: Tools for Management and Conservation

Electronic supplementary material The online version of this article (doi:10.1007/s10750-015-2530-8) contains supplementary material, which is available to authorized users.

K. Obolewski $(\bowtie)$

Department of Hydrobiology, Kazimierz Wielki

University in Bydgoszcz, 30 Chodkiewicza Str.,

85-064 Bydgoszcz, Poland

e-mail: obolewsk@apsl.edu.pl; obolewsk@ukw.edu.pl

K. Glińska-Lewczuk

Department of Water Resources, Climatology and

Environmental Management, University of Warmia and

Mazury in Olsztyn, 2 Łódzki Sq.,

10-719 Olsztyn-Kortowo, Poland

e-mail: kaga@uwm.edu.pl increased, especially the density of Oligochaeta, Malacostraca, Trichoptera, Bivalvia and Gastropoda, while the density of Diptera decreased. Water flow and physico-chemical variables were the most important factors explaining their variance. A direct inflow of water into the reconnected oxbow lakes occurred only during the first 2 years of the study, followed by silting and overgrowing of the inlet to the upper arm. We propose that creating semi-lotic side channels connected to the river with one arm and only occasionally flushed with fresh river water is one of the most effective restoration strategies. However, at the whole river scale, the maintenance of diversified hydrological connections is the optimal solution.

Keywords Wetlands - Restoration - Benthic macroinvertebrates - Water quality · Floodplain · Hydrological connectivity

\footnotetext{
M. Ożgo

Department of Evolutionary Biology, Kazimierz Wielki University in Bydgoszcz, 12 Ossolińskich Str., 85-093 Bydgoszcz, Poland e-mail: mozgo.biol@interia.pl
A. Astel
Department of Environmental Chemistry, Pomeranian University in Słupsk, 22b Arciszewskiego Str.,
76-200 Słupsk, Poland
e-mail: astel@apsl.edu.pl 


\section{Introduction}

Rehabilitation programmes are increasingly important in long-term recovery of river-floodplain systems. Strengthening hydrological integration of floodplain water bodies is one of their key principles (Schiemer, 1999; Dolédec et al., 2015), as it prevents further isolation and siltation (Dynesius \& Nilson, 1994; Ward et al., 1999) and helps mitigate biodiversity loss (Reckendorfer, 2004). Restoration of lateral connectivity includes reconnecting oxbow lakes to the main river channel, a measure allowing reactivation of geomorphological and biogeochemical processes (Benke et al., 2000; Obolewski et al., 2014a). The choice of appropriate restoration strategies requires particular knowledge of the biotic and abiotic components of ecosystems and their functions and interactions (Jansson et al., 2005; Gallardo et al., 2014; Paillex et al., 2015).

Hydrological conditions are a key morphogenetic factor, and they also shape the aquatic environment of oxbow lakes (e.g. Ward et al., 2002; Gallardo et al., 2012, 2014). Changes in water quality affect biotic components of aquatic ecosystems (e.g. Gallardo et al., 2008; Obolewski, 2011a; Martinovic-Vitanovic et al., 2013; Wilk-Woźniak et al., 2014) and are reflected in the diversity of plant and animal assemblages (Pedersen et al., 2007; Sartori et al., 2015). Assemblages of benthic fauna are particularly interesting, as their structure provides information on the ecological status of a floodplain (Obolewski et al., 2014b). Their occurrence is strongly related to hydrological connectivity in floodplains across climatic zones (Gallardo et al., 2008; Obolewski, 2011b; Gallardo et al., 2014; Obolewski et al., 2014a; Lamouroux et al., 2015). The concept of ecological approach to assessing the status of waters underlies the implementation of the Water Framework Directive (WFD) (Wright et al., 1998, 2000). As part of this implementation, the abundance and taxonomic composition of benthic invertebrates is used to assess the ecological health of aquatic ecosystems. Thanks to the relatively detailed knowledge of environmental requirements of many benthic invertebrates, the structure of their communities allowed to assess the limits of the ecological status of approximately $70 \%$ of rivers and $60 \%$ of lakes in Europe (Birk et al., 2012).

Gradients in hydrological connectivity influence the distribution of benthic macroinvertebrates in river- floodplain systems (e.g. Gallardo et al., 2008; Dolédec et al., 2015; Paillex et al., 2015), but our understanding of these relations remains fragmentary and new data and analyses are needed. This concerns particularly ecological effects of reestablishment of hydrological connectivity between the river and adjacent floodplain. Along with understanding of the threats for individual taxa, it is important to gain a better understanding of how different factors determine their diversity and distribution in reconnected water bodies.

In the present study, we analysed changes in the composition of benthic macroinvertebrate assemblages in two oxbow lakes that were reconnected to each other and to the main river channel and thus formed a river-floodplain system. We aimed in particular to answer the following questions: (i) How does the restoration of hydrological connectivity in a river-floodplain system affect water parameters and the structure of macrozoobenthos? (ii) How does a gradient of physico-chemical variables in reconnected oxbow lakes shape the diversity of benthic macroinvertebrates? (iii) What short-term ecological effects can be achieved by reconnecting isolated oxbow lakes? (iv) How can the results help in planning further floodplain restoration programmes?

\section{Materials and methods}

Study area and site description

The Słupia River is a lowland river flowing through northern Poland and discharging into the Baltic Sea. It is $139 \mathrm{~km}$ long and its drainage basin area is $1,620 \mathrm{~km}^{2}$. Its present form results largely from hydro-engineering works dating back to the mideighteenth century and continued in nineteenth and twentieth centuries. As a result, the main river channel was straightened and stabilized, and numerous side channels, weirs, dams and reservoirs were built. In the 1920 s, approximately 1,000 ha riverside meadows were drained and about fifty arms of the original braided system were cut off and became isolated oxbow lakes (Obolewski et al., 2014a).

The study was carried out along a $0.5-\mathrm{km}$-long sector of the Stupia River (Poland), (upstream: $\mathrm{N} 54^{\circ} 23^{\prime} 8.0388^{\prime \prime} / \mathrm{E} 17^{\circ} 2^{\prime} 33.5448^{\prime \prime}$; downstream: N54 $23^{\prime}$ $19.0143^{\prime \prime} / \mathrm{E} 17^{\circ} 2^{\prime} 20.374^{\prime \prime}$ ). In autumn 2008, two shallow 
oxbow lakes, approximately 90 years old, were reconnected to each other and to the main river channel (Fig. 1). Morphological characteristics of the studied oxbow lakes before and after reconnection are listed in Table 1. The oxbow OLS1 became the upstream part, and OLS2 was the downstream part of the arm.

Sampling and analytical analyses

Water and macroinvertebrate samples were collected in spring, summer, autumn and winter before restoration in 2008 (i.e. $T+0$ ) and 1, 3, 4 and 5 years after restoration $(T+1, T+3, T+4, T+5$, respectively). In $T+3$ samples were not collected in winter. Before the reconnection, water and macroinvertebrate samples were collected from two sites in the arms (sites A and C) and one in the middle part of both oxbow lakes (sites B). After the reconnection, site A' was added at the mouth of the newly built upstream arm (Fig. 1) to satisfy equal distribution of sampling sites. In total 114 samples were collected (2008, $n=24 ; 2009, n=24 ; 2011, n=18 ; 2012, n=24$;
2013, $n=24)$. Data from OLS1 and OLS2 after restoration were analysed together, as consideration of individual sampling sites brings results that are difficult to interpret and to track overall changes brought about by restoration (see e.g. Obolewski et al., 2014a).

Water flow (Q) was measured at the time of sampling at the inflow and outflow sites (Fig. 2A, B). The method depended on the volume of water. In most cases, an electromagnetic flow velocity sensor (FlowSens-model 801, Valeport, UK) was used and the discharge was calculated using the standard velocityarea method. Low flows $\left(Q<5.0 \mathrm{dm}^{3} \mathrm{~s}^{-1}\right)$ were determined with the volumetric method. Additionally, water-level dataloggers (Mini-Diver@, Van Essen Instr., the Netherlands) were installed at the sampling sites.

Dissolved oxygen (DO), water temperature, electrical conductivity (EC), $\mathrm{NO}_{3}{ }^{-}-\mathrm{N}, \mathrm{NO}_{2}{ }^{-}-\mathrm{N}, \mathrm{NH}_{4}{ }^{+}-\mathrm{N}$ and $\mathrm{pH}$ were measured in situ with calibrated multiparametric portable probes YSI 6600R2 (YSI, USA). Water samples were collected from the depth of
Fig. 1 Hydrological system of the Słupia River before its regulation (1893) and after restoration (2008) which involved reconnection of oxbow lakes (OLS1 and OLS2) to the main channel

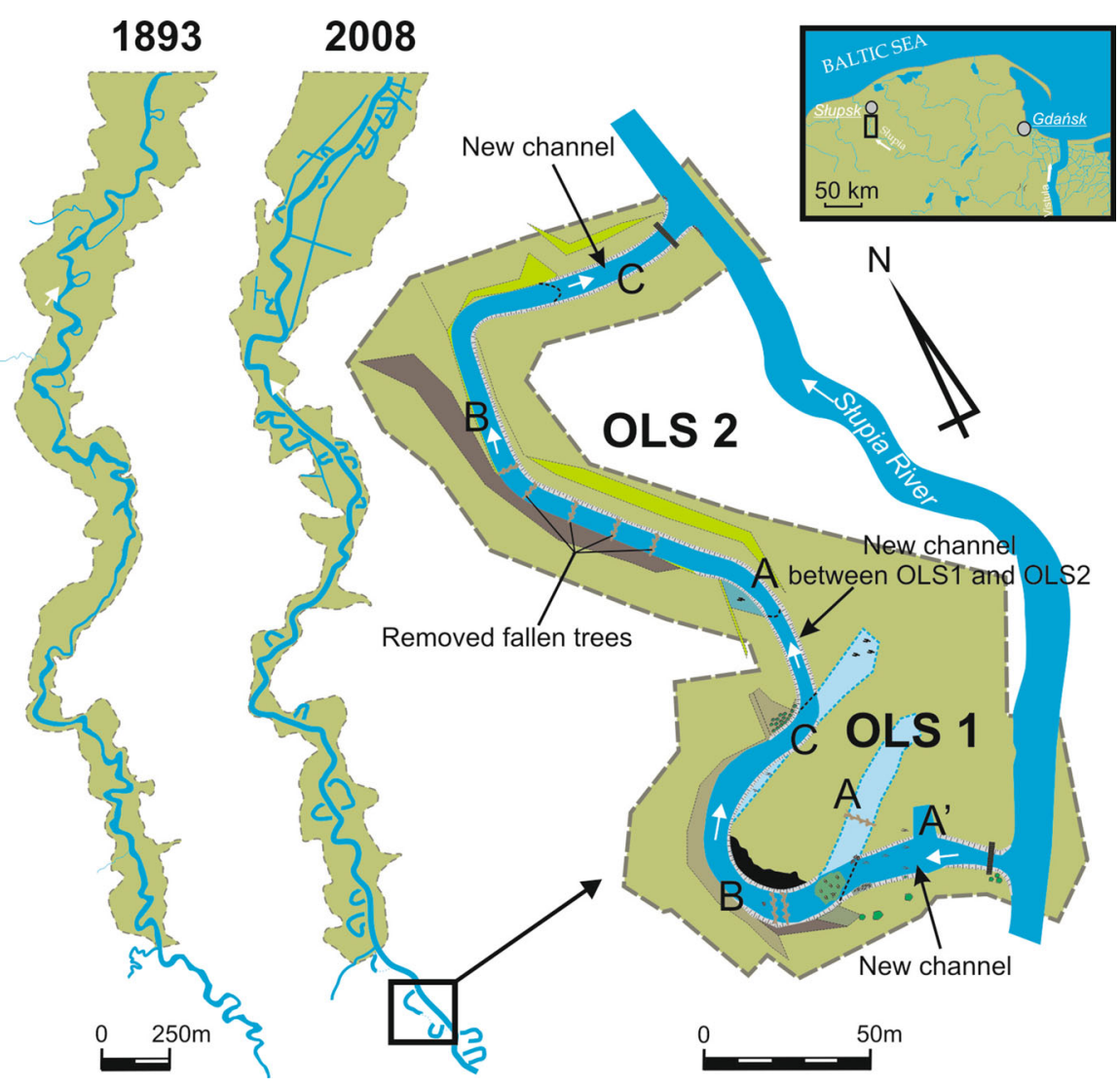




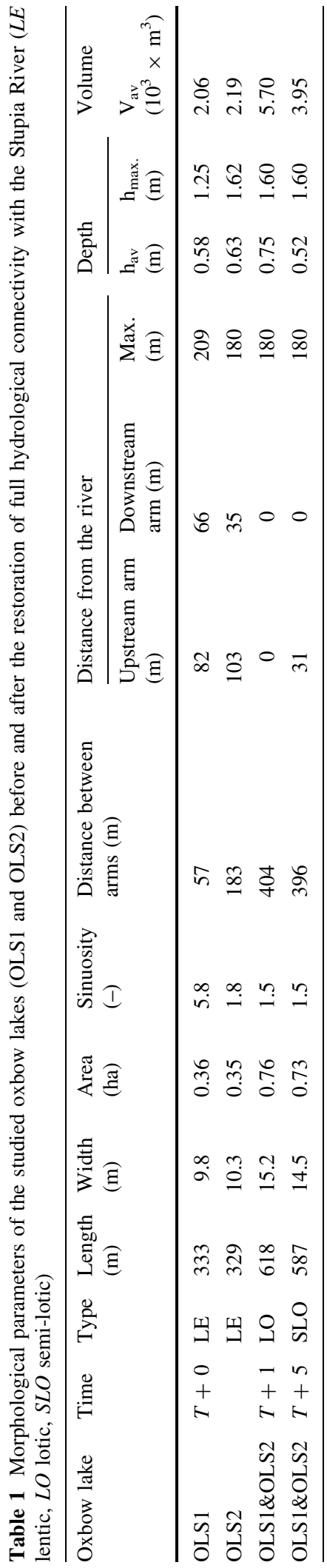

10-20 cm into 2-L polyethylene bottles washed with $2 \mathrm{M}$ hydrochloric acid and rinsed several times with distilled water. Concentrations of cations and anions $\left(\mathrm{Cl}^{-}, \mathrm{SO}_{4}{ }^{2-}, \mathrm{K}^{+}, \mathrm{Ca}^{2+}, \mathrm{Mg}^{2+}\right.$ and $\left.\mathrm{Na}^{+}\right)$were determined with ion chromatography (Methrom 881 Compact IC pro, USA). Total phosphorus (TP) and phosphate phosphorus $\left(\mathrm{PO}_{4}{ }^{3-}-\mathrm{P}\right)$ were determined with constant flow analyser FLOWSYS-SYSTEA ${ }^{\circledR}$ (APHA, 1989). The quantity of mineral matter (MM) was determined after ashing at $450^{\circ} \mathrm{C}$ for $4 \mathrm{~h}$. Chemical oxygen demand (COD) and the concentration of $\mathrm{HCO}_{3}{ }^{-}$were measured with DR-2800 spectrophotometer (Hach-Lange, USA) using cuvette methodology. To assess the trophic status of the studied floodplain lakes, the trophic state index based on total phosphorus $\left(\mathrm{TSI}_{\mathrm{TP}}\right)$ was calculated according to Carlson (1977); the lakes were classified according to Carlson \& Simpson (1996).

Macroinvertebrate samples were collected in three replicates with the Ekman bottom grab sampler $\left(225 \mathrm{~cm}^{2}\right.$ surface area). Sampling sites differed in the thickness of sediments and their composition (e.g. the presence of leaves, branches and submerged plants). Samples were sieved through a $400-\mu \mathrm{m}$ mesh size sieve and fixed in 5\% formalin. In the laboratory, benthic organisms were identified to the lowest possible systematic level, in most cases to genus or species.

\section{Statistical analyses}

The following ecological indices were used: Shannon diversity index (H') (Krebs, 1999), Pielou's evenness index (J') (Pielou, 1966), relative density, genus richness and total abundance. $\mathrm{H}^{\prime}$ and $\mathrm{J}$ ' indices were calculated with Past v.2.17c (Hammer et al., 2001).

Significance of differences in physico-chemical parameters of water and abundance of macroinvertebrates between pre- and post-restoration periods were assessed with non-parametric analysis of variance. Kruskal-Wallis's test $(K-W)$ with post hoc Dunn's test was carried out with GraphPad Prism 5.01 (GraphPad Software, Inc., La Jolla, USA). The response of the macrozoobenthos communities to environmental conditions was explored using methods of multivariate statistical analysis, such as detrended correspondence analysis (DCA) and canonical correspondence analysis (CCA). To reduce the effect of absolute values, the abundances of the invertebrate 
Fig. 2 A Hydrograph of the Słupia River extrapolated from a gauge station in Słupsk to the study site in $T+0, T+1, T+3, T+4$ and $T+5$. The levels of BFL (bankfull level) and HWL (high water level) have been calculated for the period of 1999-2013. Arrows with "s" denote sampling times. B Discharge $(Q)$ in the upstream (OLS1) and downstream (OLS2) arms after restoration
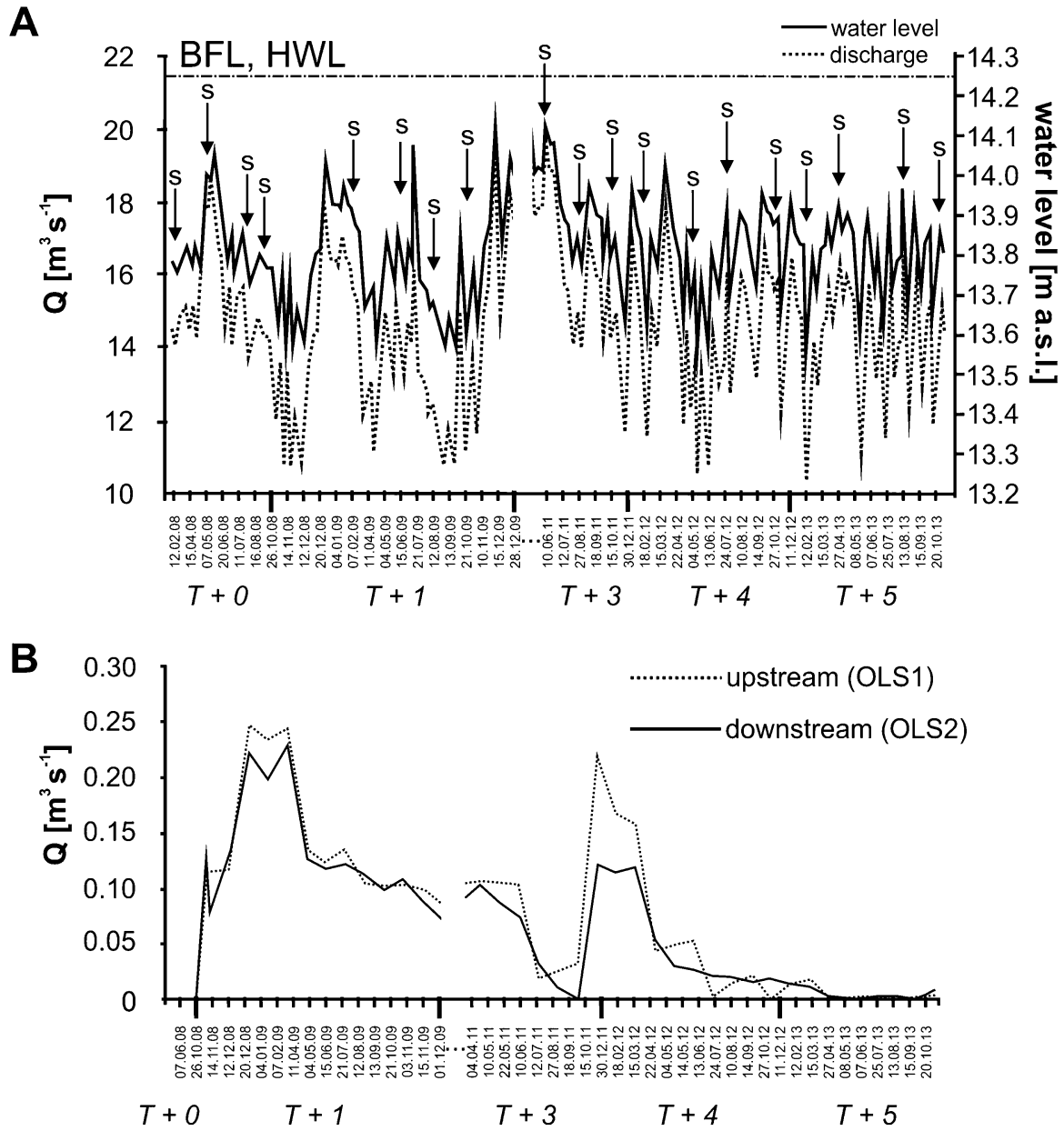

densities were square-root transformed $(\sqrt{X+1})$, rare species were downweighted and environmental data were log-transformed $\left(\log _{10}(X+1)\right)$ (ter Braak \& Šmilauer, 2002). As recommended by Lepš \& Šmilauer (2003) and ter Braak \& Smilauer (2002), DCA was used to decide between the use of linear (the first axis shorter than $3 \mathrm{SD}$ ) or unimodal (the first axis longer than $4 \mathrm{SD}$ ) ordination methods. As the length of the first DCA axis equaled 2.98 SD, CCA was further used to obtain an overview of the combined effects of discharge and water quality parameters at the community level. Statistical significance of the canonical axes was determined using Monte Carlo permutation tests. Forward selection was applied to find a sufficient subset of the explanatory variables that represented relations between the species/taxon and environmental data. Multivariate analyses were performed with CANOCO 4.5 for Windows (ter Braak \& Smilauer, 2002).

\section{Results}

Hydrological characteristics

In the study period, water levels ranged by approximately $1 \mathrm{~m}$, with high frequency changes of water flow (Fig. 2A, B). The average water flow in the Słupia River at a gauging station in the town of Słupsk was $16 \mathrm{~m}^{3} \mathrm{~s}^{-1}$, ranging from 10 to $20 \mathrm{~m}^{3} \mathrm{~s}^{-1}$ (Fig. 2A). Relatively uniform discharge throughout the year did not generate extreme phenomena such as low flows or floods; water flew into the experimentally connected oxbow lakes only through the newly built channels connecting the oxbow arms with the main river channel.

Water level and flow rate dynamics changed widely in the restored arm created after reconnecting the oxbow lakes with the main river. However, this effect was short-lasting (Fig. 2B). The increased water flow 
rate observed from autumn $T+0$ to spring $T+1$ and from autumn $T+3$ to spring $T+4$, with average flow rate values of 0.14 and $0.18 \mathrm{~m}^{3} \mathrm{~s}^{-1}$, respectively, was followed by a decrease observed since the summer of $T+4$, when the average flow rate was $0.05 \mathrm{~m}^{3} \mathrm{~s}^{-1}$. Differences in flow rate values between $T+5$ (the last year of study) and $T+1$ (the first year of the study after restoration) and $T+4$ were statistically significant (Dunn's test, $P<0.0001$ and $P<0.05$, respectively). Reconnection of oxbow lakes resulted in changes of water flow in the upstream (OLS1) and downstream (OLS2) arms (Fig. 2B). In $T+5$, the connection of the upstream arm with the river was blocked again. Since then, the restored system has remained connected to the river channel only with its downstream arm.

\section{Physico-chemical conditions}

After re-establishing hydrological connectivity of the experimental river-floodplain system, 17 out of 20 analysed water parameters changed significantly (Table 2). There was a great interannual variability. EC and pH differed significantly among the years of the study $(K-W=29.88, P<0.001$ and $K-W=38.74)$; the differences were most pronounced between $T+0$ and $T+3$ and $T+4$ (Dunn's test, $P<0.01$ ). Similarly, dissolved oxygen concentration changed significantly in reconnected oxbow lakes $(K-W=41.20$, $P<0.001$ for DO and DO $; K-W=16.41, P<0.01$ for COD). DO and DO\% increased significantly after reconnection and subsequently decreased. The difference in COD was statistically significant only between $T+1$ and $T+3$ (Dunn's test, $P<0.001$ ). Concentrations of mineral nitrogen forms changed significantly between years. After the connection was established, concentrations of $\mathrm{NO}_{3}{ }^{-}-\mathrm{N}$ and $\mathrm{NH}_{4}{ }^{+}-\mathrm{N}$ increased (Dunn's test, $P<0.001$ and $P<0.05$, respectively), but subsequently were oscillating around lower values (Table 2). There were considerable fluctuations in the values of Carlson's trophic state index TSI (TSI $_{\mathrm{TP}}, K-W=37.10, P<0.001$ ), especially pronounced before and after establishing hydrological connectivity (Dunn's test, $P<0.001$ ). TP and $\mathrm{PO}_{4}{ }^{3-}$-P concentrations decreased significantly (TP,

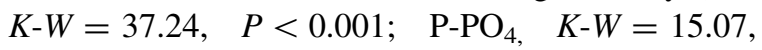
$P<0.01)$ after the connection with the river was opened. The high value of $\mathrm{TSI}_{\mathrm{TP}}$ indicates that water quality in the study system was typical for hypertrophic habitats. Concentration of hydrogen carbonates changed significantly after restoration $(K-W=27.01-$ 15.57, $P<0.01$ ) especially between $T+0$ and $T+4$ (Dunn's test, $P<0.01$ ). Significant changes in the concentration of chlorides $(K-W=11.99, P<0.05)$ concerned only the time between $T+3$ and $T+5$ (Dunn's test, $P<0.05$, Table 2).

Patterns of macroinvertebrate abundance

Changes in hydrological connectivity of the experimental river-floodplain system resulted in significant changes in the composition and abundance of benthic macroinvertebrates (Table 3). Soon after the reconnection $(T+1)$, their densities increased 1.5 times, with significant differences over the study period $(K-$ $W=23.44, P<0.001)$. The most pronounced differences were observed between $T+1$ and $T+4$ (Dunn's test, $P<0.01$ ) and between $T+1$ and $T+3(P<0.05)$. Similarly, the number of identified taxa decreased significantly $(K-W=18.68$, $P<0.001$ ), especially between $T+1$ and $T+3$ (Dunn's test, $P<0.05$ ). A significant increase in the values of the Shannon diversity index $\left(\mathrm{H}^{\prime}\right)$ and Pielou's evenness index (J') was observed over time $(K-W=10.60, P<0.05$ and $K-W=15.11, P<$ 0.01 , respectively); both indices showed a generally increasing trend, except for $T+3$.

In total, 7,360 individuals belonging to 34 species, 18 genera and 2 higher taxa were identified (Table 1 in Online Appendix). Malacostraca were the most numerous class, both before and after reconnection amounting to $34 \%$ of all individuals at $T+0$ and $26 \%$ at $T+1$ to $T+5$. Changes in their densities were significant over time $(K-W=22.05, P<0.001)$ with mean densities increasing dramatically after restoration (Dunn's test, $P<0.05$, Table 3). Oligochaeta were the second most numerous group and their relative densities also increased significantly $(K-$ $W=14.90, P<0.01$, Table 1 in Online Appendix), especially between $T+4$ and $T+5$ (Dunn's test, $P<0.05$, Table 3). Similarly, significant increases were observed in the densities of Trichoptera $(K-$ $W=18.67, P<0.001)$, Gastropoda $(K-W=17.42$, $P<0.01)$ and Bivalvia $(K-W=10.52, P<0.05)$, while significant decrease was observed only in the densities of Diptera larvae $(K-W=19.26$, $P<0.001)$. No alien or threatened species were observed before or after restoration. 


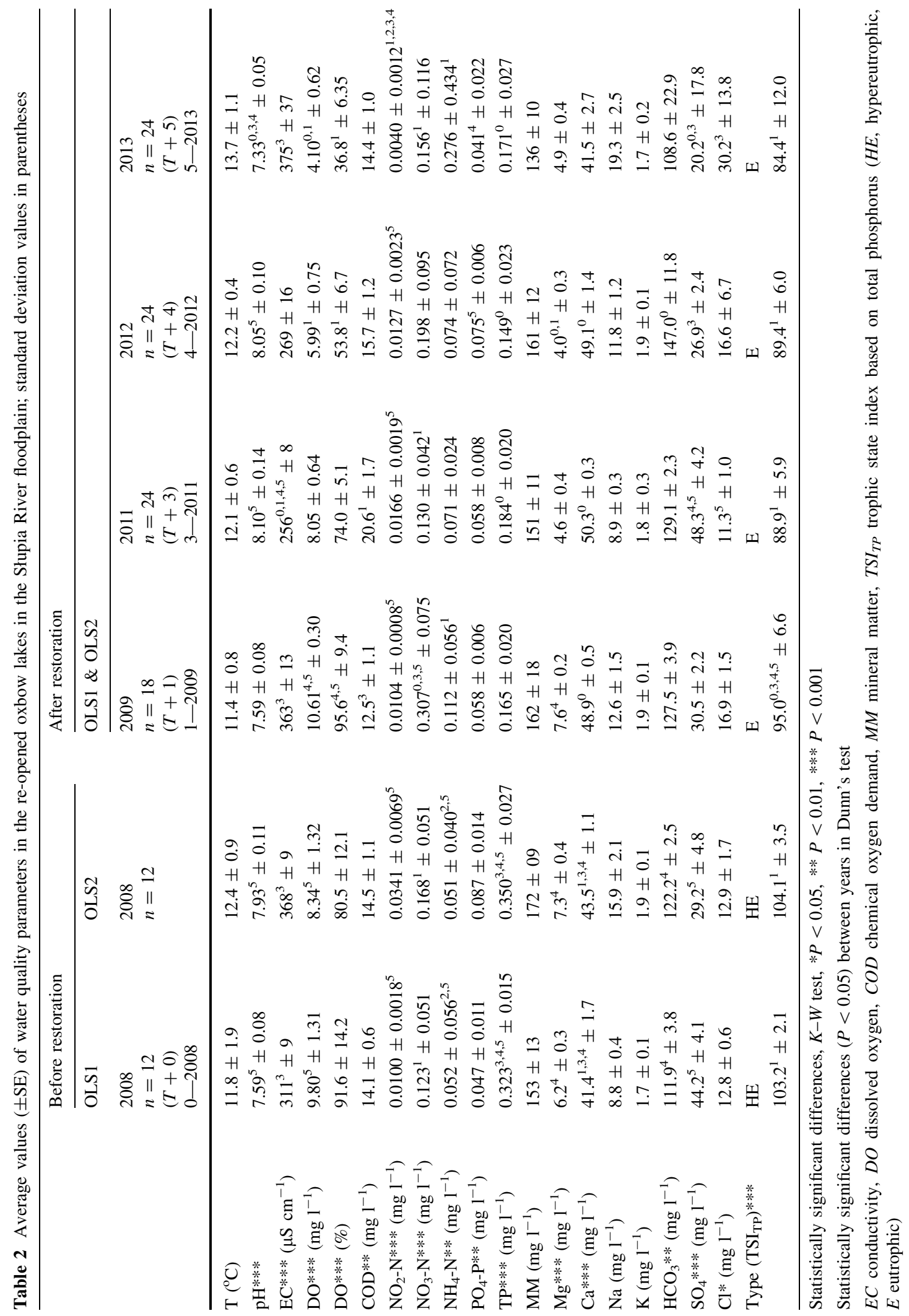


The upstream arm (OLS1) and downstream arm (OLS2) differed in faunal diversity. When the lakes were cut off from the river, a larger number of macroinvertebrate species were observed in OLS2 than in OLS1 (Fig. 3A, B). However, the abundances were higher in OLS1 and subsequently in the upstream arm it formed (Fig. 3C, D).

In the first year after reconnection $(T+1)$, a dynamic increase in the number of species and abundance of benthic macroinvertebrates was observed in both arms of the system. In the third year $(T+3)$, a decrease in all analysed indices occurred, particularly pronounced in the lower arm (Fig. 3B, D, H). During two subsequent years, an increase in richness, abundance and diversity was observed in both arms of the restored system. In the upstream arm, the Pielou's index of evenness (J') remained relatively constant, while in the downstream arm the changes were statistically significant $(K-W=13.08, P<0.05)$.
Primary gradients affecting aquatic community structure

The CCA model summarizes the relations between the macroinvertebrate species composition and environmental parameters (Fig. 4A). Among 20 analysed variables, seven had a significant effect on benthic macroinvertebrates (Table 4). Space variables (OLS1 and OLS2) have been excluded from further CCA analysis as they were redundant variables in step-wise regression (forward selection) with Monte Carlo test. The final model explained $77.8 \%$ of the total variance in the structure of macrozoobenthos. All canonical axes were significant (Monte Carlo test, $P<0.01$ ). The first CCA axis shows mostly the effect of the rate of water flow and oxygen concentrations, while the second one the effect of $\mathrm{Cl}^{-}$and $\mathrm{Na}^{+}$(Fig. 4A).

CCA analysis also indicated considerable changes in the composition of macroinvertebrate assemblages

Table 3 Mean densities (indiv. $\mathrm{m}^{-2} \pm \mathrm{SE}$ ) of invertebrates in the studied oxbow lakes (OLS1 and OLS2) in the Słupia River before (2008) and after restoration works (2009 and 2011-2013)

\begin{tabular}{|c|c|c|c|c|c|c|}
\hline & \multicolumn{2}{|c|}{ Before restoration } & \multicolumn{4}{|l|}{ After restoration } \\
\hline & \multirow{2}{*}{$\begin{array}{l}\text { OLS1 } \\
2008 \\
n=12 \\
(T+0) \\
0-2008\end{array}$} & \multirow{2}{*}{$\begin{array}{l}\text { OLS2 } \\
2008 \\
n=12\end{array}$} & \multicolumn{4}{|l|}{ OLS1 \& OLS2 } \\
\hline & & & $\begin{array}{l}2009 \\
n=18 \\
(T+1) \\
1-2009\end{array}$ & $\begin{array}{l}2011 \\
n=24 \\
(T+3) \\
3-2011\end{array}$ & $\begin{array}{l}2012 \\
n=24 \\
(T+4) \\
4-2012\end{array}$ & $\begin{array}{l}2013 \\
n=24 \\
(T+5) \\
5-2013\end{array}$ \\
\hline Oligochaeta** & $44.4 \pm 28.9$ & $161.3 \pm 125.4$ & $139.4 \pm 37.4$ & $125.8 \pm 79.6$ & $135.8^{5} \pm 117.2$ & $907.8^{4} \pm 528.6$ \\
\hline Hirudinea & $34.6 \pm 11.8$ & $19.8 \pm 6.5$ & $67.3 \pm 13.7$ & $27.2 \pm 13.4$ & $76.5 \pm 52.8$ & $45.2 \pm 11.5$ \\
\hline Malacostraca*** & $375.3 \pm 266.1$ & $319.3 \pm 200.1$ & $2223.9^{3,4,5} \pm 570.5$ & $29.7^{1} \pm 16.2$ & $28.8^{1} \pm 11.5$ & $72.5^{1} \pm 28.7$ \\
\hline Plecoptera & 0.0 & 0.0 & 0.0 & 0.0 & $3.3 \pm 3.3$ & 0.0 \\
\hline Odonata & $4.9 \pm 3.5$ & 0.0 & $9.3 \pm 5.8$ & 0.0 & $0.8 \pm 2.4$ & $2.5 \pm 1.8$ \\
\hline Ephemeroptera** & $49.4 \pm 32.4$ & $37.9 \pm 20.8$ & $105.5^{4} \pm 40.2$ & 0.0 & $0.8^{1} \pm 0.8$ & $46.9 \pm 100.6$ \\
\hline Megaloptera & $6.6 \pm 6.6$ & $29.6 \pm 14.8$ & $37.0 \pm 11.9$ & $65.4 \pm 34.0$ & $5.8 \pm 5.0$ & $23.9 \pm 9.4$ \\
\hline Coleoptera & 0.0 & $3.3 \pm 2.2$ & $3.7 \pm 2.0$ & 0.0 & $1.7 \pm 1.6$ & 0.0 \\
\hline Trichoptera*** & $13.2^{1} \pm 10.0$ & $3.3^{1} \pm 3.3$ & $104.9^{0,4,5} \pm 44.8$ & 0.0 & $9.9^{1} \pm 6.0$ & $7.4^{1} \pm 5.9$ \\
\hline Hemiptera & $3.3 \pm 3.3$ & $1.6 \pm 1.6$ & $14.8 \pm 32.8$ & 0.0 & $1.6 \pm 1.1$ & $14.0 \pm 9.4$ \\
\hline Diptera $^{* * *}$ & $734.2 \pm 467.5$ & $220.6 \pm 154.6$ & $134.5 \pm 37.0$ & $25.9^{5} \pm 20.1$ & $19.7^{5} \pm 12.6$ & $685.2^{3,4} \pm 222.6$ \\
\hline Lepidoptera & 0.0 & 0.0 & 0.0 & 0.0 & $0.8 \pm 0.8$ & 0.0 \\
\hline Gastropoda** & $3.3^{4,5} \pm 3.3$ & $6.6^{4,5} \pm 6.6$ & $83.9 \pm 43.7$ & $11.1 \pm 9.8$ & $53.3^{0} \pm 12.9$ & $86.4^{0} \pm 34.4$ \\
\hline Bivalvia* & $21.4 \pm 14.6$ & $23.0 \pm 14.4$ & $60.5 \pm 19.1$ & $67.9 \pm 56.3$ & $29.6^{5} \pm 15.3$ & $98.2^{4} \pm 36.9$ \\
\hline
\end{tabular}

Statistically significant differences, $K-W$ test, $* P<0.05, * * P<0.01, * * * P<0.001$

Statistically significant differences $(P<0.05)$ between years in Dunn's test 
related to fluctuations of water level or flow resulting from the reestablished hydrological connectivity and considerable differences in environmental conditions (e.g. concentration of organic and inorganic matter, Fig. 4A). Analysis showed that the water flow along the OLS1 and OLS2 affected all studied taxa (Fig. 4C). The strongest response was observed in Plecoptera, while Odonata larvae were the least affected. Different groups of macrozoobenthos were differently affected by the changes in water flow. At low rates, the increase in the abundance of only $40 \%$ of species was observed, while the abundance of the majority of studied taxa was highest at $0.08-0.16 \mathrm{~m}^{3} \mathrm{~s}^{-1}$, and only few species of Mollusca, Hirudinea and Oligochaeta occurred at $Q>0.16 \mathrm{~m}^{3} \mathrm{~s}^{-1}$.

\section{Discussion}

The interdependence between river channel and floodplain lakes is reflected in complex functions of matter circulation, which are determined by periodical flooding and fluctuations in the water level (Aspetsberger et al., 2002). This stimulates an increase in biodiversity and productivity of floodplains (Reese \& Batzer, 2007; Sartori et al., 2015). Natural fluctuations of water levels in the Słupia River were recently altered by the operation of water power plants upstream of the study area, and for a few years mainly low and mean water levels were observed (Obolewski, 2011b). This situation also affected the results of our study (Fig. 2A), where, between 2008 and 2013, there was no flood and therefore no exchange of water between the floodplain and the river. With increasing duration of floodplain isolation due, to a high degree, to climate change, it can be expected that wetland restoration will soon become the major way to protect floodplain ecosystems (King et al., 2009; Breithaupt \& Khangaonkar, 2011; Č́ízková et al., 2013). As emphasized by Ward et al. (1999), the basis of restoration is to reestablish connectivity between the river channel and the floodplain and to ensure the diversity of the dynamics of water flow through these ecosystems. These assumptions were applied in the restoration of the Słupia River oxbow lakes, where it was sought to differentiate the flow rate of water through reconnected wetlands (Fig. 2B). Until autumn 2008, there was no permanent connection between the lakes and the river. Earthworks carried out in November 2008 restored the exchange of water by opening the meander necks and connecting the two oxbow lakes (OLS1 and OLS2). Before reconnection, the two studied reservoirs were lentic oxbow lakes (plesiopotamic) characterized by low heterogeneity of habitats, and therefore it is difficult to colonize by various groups of macroinvertebrates (e.g. Gallardo et al., 2008; Wilk-Woźniak et al., 2014). Dredging of the ditches allowed migration of species between the reconnected oxbow lakes and the river. The observed rates of colonization of the reconnected oxbow lakes were similar to those reported in other studies (e.g. Pedersen et al., 2007). Habitat availability is the main reason for downstream drift and the condition for recolonization (Matthaei et al., 1997). Macroinvertebrate assemblages in the restored middle reaches of the River Słupia are diverse, and in refugia they can reach considerable abundances (Obolewski, 2011b). The results of the present study indicate that in the floodplains of medium-sized rivers resilience can be high and recolonization of available habitats, including floodplain wetlands, can occur rapidly (Friberg et al., 1998). Reestablished hydrological connections can potentially be used for a prolonged period of time by macroinvertebrate assemblages identified in this study (Table 3 and Table 1 in Online Appendix). This is due to the formation of various refuges for many species of fauna (Pedersen et al., 2007). According to Hildrew \& Giller (1994), the morphology of the reconnected oxbows stabilizes with time, and the heterogeneity of their habitats increases. In the case of macroinvertebrate assemblages, biotic interactions become increasingly important (Lepori et al., 2005; Sartori et al., 2015). The presented results show that such relations occur in the Słupia river-floodplain system and are reflected in an increase in the diversity and abundance of benthic fauna (Table 3). Our results are contrary to the results of Roni et al. (2006) who observed no changes in the assemblages of macroinvertebrates after restoration. An important issue in reestablished hydrological connectivity is a potential risk of the dispersal of invasive species coming from the main channel and preferring lotic systems or, on the other hand, of a decrease in the number of threatened species adapted to lentic environments (Paillex et al., 2013, 2015). Biological monitoring of the Słupia River has been carried out since 2000. Of invasive species, only Dreissena polymorpha Pall. was observed and only in a retention reservoir $20 \mathrm{~km}$ 

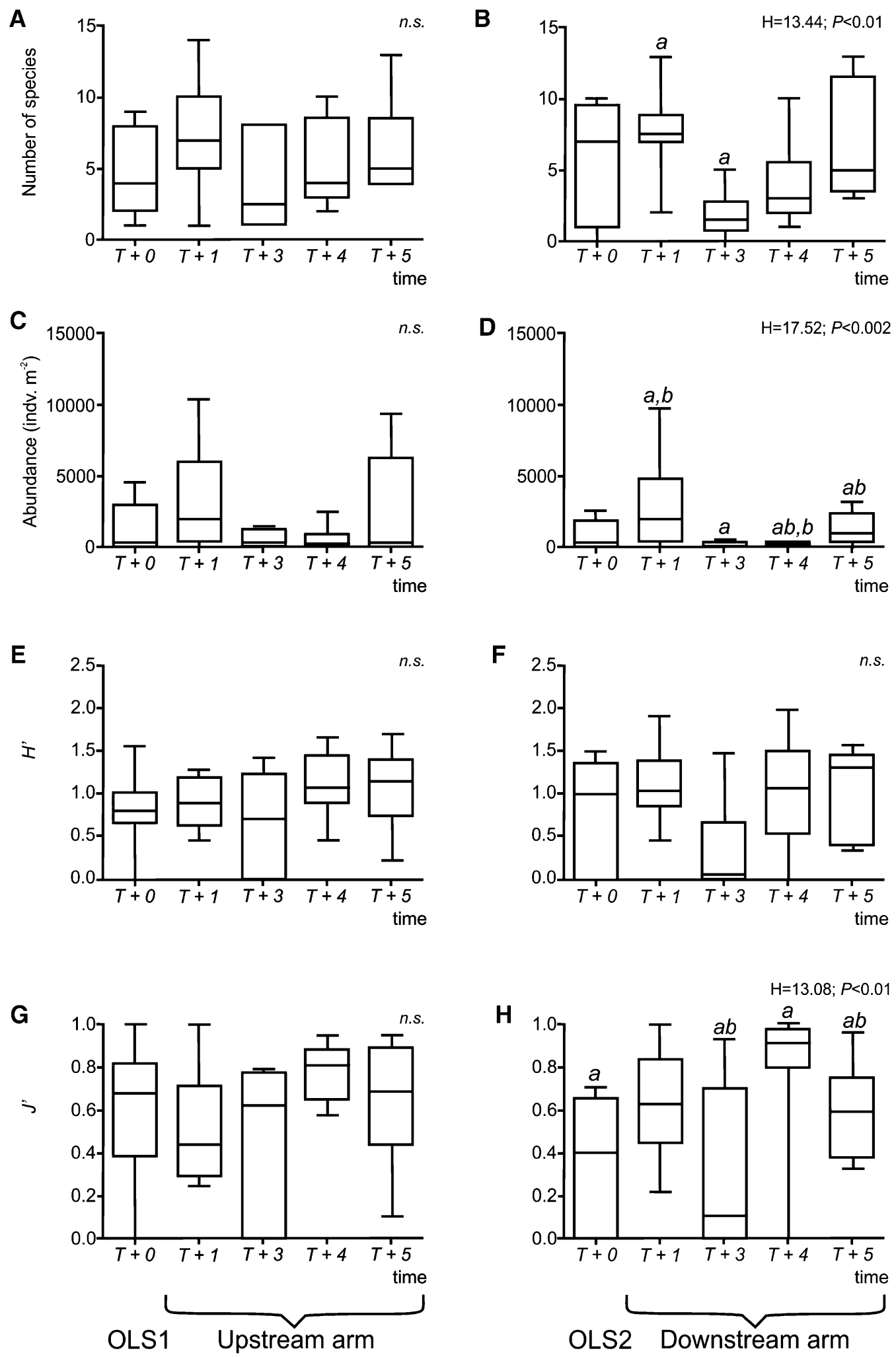
4Fig. 3 Number of species, abundance, Shannon diversity index (H') and Pielou's evenness index (J'): A, C, E, G-upstream arm (OLS1); B, D, F, H-downstream arm (OLS2). (KruskalWallis test, A $P>0.05$, B $P<0.01$, C $P>0.05$, D $P<0.002$, E $P>0.05, \mathbf{F} P>0.05$, G $P>0.05$, H $P<0.01$. Dunn's test, a or ab, $P<0.05$ and b, $P<0.01 . \mathrm{n}_{T+0}=24, \mathrm{n}_{T+1}=24$, $\left.\mathrm{n}_{T+3}=18, \mathrm{n}_{T+4}=24, \mathrm{n}_{T+5}=24\right)$

upstream of the study area (Obolewski, 2008). Several rare and/or protected fish species occur in the river, e.g. Rhodeus sericeus amarus Bloch, Cottus gobio L., Cobitis taenia L. or Salmo trutta L. Although none could have been affected by the restoration carried out in the present study, such risk should be taken into consideration in restoration programmes (Paillex et al., 2015).

The presented results indicate that the reconstructed connectivity with the river is difficult to maintain, even in the short time frame (about 5 years). We observed a strong inflow of water into the reconnected oxbow lakes only in the first period (approximately 2 years), followed by slow silting and overgrowing of the inlet to the upper arm (Fig. 2B). However, the loss of full connectivity in the river-floodplain system had little bearing on the diversity of macroinvertebrates
Fig. 4 A Ordination diagram of canonical correspondence analysis for macroinvertebrate taxa and hydrological and hydrochemical properties of water in reconnected oxbow lakes. B Relative densities of macroinvertebrate taxa before and after restoration. C Relative densities of macroinvertebrate taxa in relation to water flow
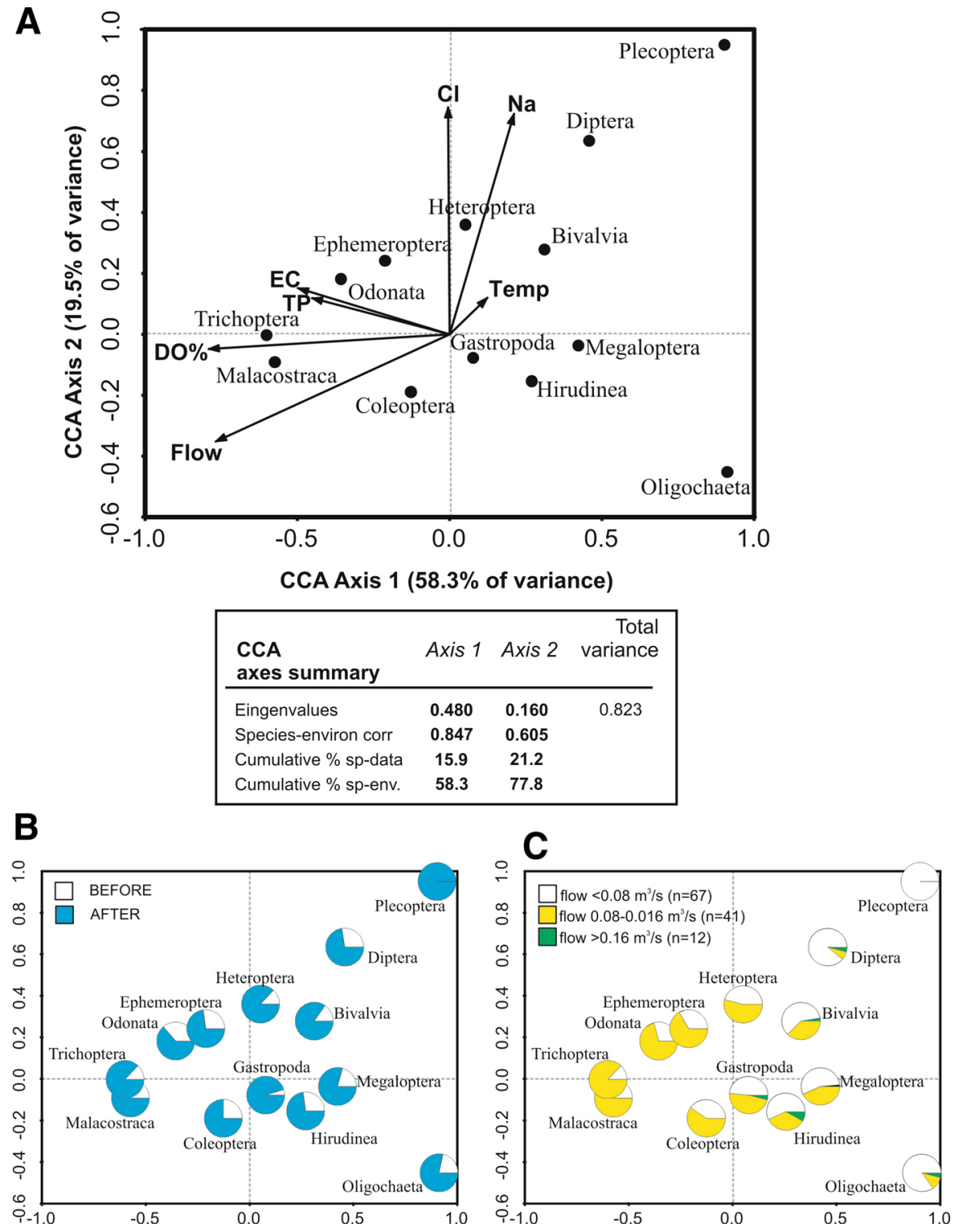
Table 4 Selected explanatory variables representing significant relations between the species and environmental data

\begin{tabular}{lllll}
\hline Variables & Marginal effects & \multicolumn{3}{c}{ Conditional effects } \\
\cline { 3 - 5 } & $\lambda \# 1$ & $\lambda$ A & $P$ value & $F$-ratio \\
\hline Flow & 0.31 & 0.31 & 0.002 & 10.37 \\
DO\% & 0.31 & 0.08 & 0.034 & 3.04 \\
EC & 0.15 & 0.10 & 0.018 & 3.60 \\
TP & 0.11 & 0.08 & 0.032 & 3.17 \\
$\mathrm{Cl}^{-}$ & 0.10 & 0.10 & 0.022 & 3.42 \\
$\mathrm{Temperature}^{-}$ & 0.07 & 0.09 & 0.016 & 3.35 \\
$\mathrm{Na}^{+}$ & 0.11 & 0.02 & 0.036 & 2.98 \\
\hline
\end{tabular}

\#Lambda $(\lambda)$ denotes the amount of variability in the species data that would be explained by a constrained ordination model using that variable as the only explanatory variable. Variables not used in the table were statistically insignificant

within the constructed wetland or its components (Table 3, Fig. 3E, F). This may be related, as has been noted by Cooper et al. (2000), to the limited penetration of half-open water bodies by fish fauna and increased heterogeneity of habitats. According to Glińska-Lewczuk \& Burandt (2011), the semi-lotic type of oxbows is optimal and sustainable, conducive to good ecosystem condition, while Paillex et al. (2009, 2015) demonstrated that increasing the level of connectivity of river-floodplain ecosystems promotes species diversity and relative abundance of new species. However, establishing full connectivity with the river (i.e. with both up- and downstream arms) of different types of oxbows (semi-lotic and lentic) brings different effects. Obolewski et al. (2014a) demonstrated that recovering full hydrological connectivity of an existing semi-lotic oxbow lake does not result in a sharp increase in species richness and abundance of benthic fauna. Opening of an oxbow lake of this type resulted in an increase in the number of macroinvertebrate taxa from 20 to 40 , while in the present study the increase was from 17 to 52 taxa. Biological diversity (Shannon index) increased slightly (from 2.7 to 2.9 ) after opening of both sides of a semi-lotic oxbow lake, while in the present study the increase was from 2.4 to 3.8. Following the reestablishment of hydrological connectivity of riverfloodplain systems, significant increase is usually observed in Trichoptera larvae (Parkyn et al., 2003); in this study, such an increase was also observed in Malacostraca (mainly Asellus aquaticus, Table 1 in
Online Appendix). The present analysis shows that restoration of floodplains facilitates the dispersal of a large group of macroinvertebrates.

Our study demonstrates the significance of the hydrological factor (flow rate) in qualitative and quantitative structuring of macrozoobenthos (Table 4). CCA confirmed the importance of horizontal water movement and changes in the condition of habitats for the obtained biological results (Fig. 4A). Abundance of most of the identified macroinvertebrates increased after opening of the oxbow lakes (Fig. 4B); the most favourable flow rate was in the range of $0.08-0.16 \mathrm{~m}^{3} \mathrm{~s}^{-1}$ (Fig. 4C). Gallardo et al. (2008) demonstrated that the diversity of benthic macroinvertebrates increased with increasing hydrological connectivity. The present study supplements this information by showing that in addition to the level of hydrological connectivity, the rate of water flow within the floodplain lakes constitutes an important factor. Along with the action of physical factors, chemical properties of the water, which in the reconnected oxbow lakes underwent prominent changes, were essential to the life of benthic macroinvertebrates (Table 2). This confirms earlier reports by Ward et al. (1999) showing a hierarchical interdependence of the hydrological, hydrochemical and biological variables in wetland areas. Concentration of dissolved oxygen belongs to the most important chemical components determining the taxonomical and functional structure of macroinvertebrates. Its increase in the water of reconnected oxbow lakes was caused by the inflow of well-aerated river water and resulted in the appearance of species that are less tolerant to oxygen shortage (e.g. Gammarus fossarum, Leuctra sp.) and in a sharp decrease in the abundance of species resistant to oxygen deficits, e.g. Chironomus f.l. plumosus, which occurs at DO concentrations of less than $2 \mathrm{mg} \mathrm{dm}^{-3}$ (Turoboyski, 1979; Mandaville, 2002). Significant influence of conductivity was associated with high concentrations of ions, of which only the $\mathrm{Na}^{+}$and $\mathrm{Cl}^{-}$were identified in the CCA analysis. Another important component determining resource conditions for macroinvertebrate communities is the concentration of nutrients (Gallardo et al., 2008; Obolewski, 2011b). In light of the present analysis, phosphorus seems to be a particularly important nutrient, as three groups of larvae: Odonata, Ephemeroptera and Trichoptera were associated with its concentration (Fig. 4A). In other studies on the 
correlations between the structure of macrozoobenthos and the condition of oxbow lake habitats, the importance of nitrate nitrogen (Gallardo et al., 2008) or nitrite nitrogen (Obolewski, 2011b) was shown. Our research suggests that phosphorus can also be an important factor. All reports indicating the influence of nutrients on the abundance of invertebrates indicate the importance of improved hydrological connectivity within the river floodplain.

Our results demonstrate that, regardless of its persistence, the facilitation of river water flow through cut off lakes is of fundamental importance for the functioning of oxbow lake ecosystems, because the enhanced flushing can improve the aquatic ecosystem metabolism (Grosholz \& Gallo, 2006; Gallardo et al., 2012). However, at the scale of the entire riverfloodplain system, only a diversified lateral connectivity can ensure a better protection of biodiversity (Castella et al., 2015; Paillex et al., 2015).

\section{Conclusions}

The results of this study increase the knowledge on the impact of conservation methods aimed at improving the habitat conditions of floodplain lakes. Most lowland rivers in Europe are strongly degraded and so they increasingly become objects of restoration programmes. However, re-meandering treatments do not necessarily lead to the reconstruction of highly diverse fauna. Although this study considers only short-term biological effects of hydrological reconnection of floodplain lakes, it shows that such treatment substantially improves the diversity and abundance of macroinvertebrates. This improvement is higher in the case of half-open oxbow lakes, and therefore spontaneous emergence of this kind of hydraulic system perpetuates the increase of the abundance and biodiversity of macrozoobenthos. Therefore, construction of river-floodplain systems connected with the river with only one arm seems to be useful and relatively stable approach. However, although a reconnection is an appropriate strategy to rejuvenate a disconnected channel, at the scale of an entire river diversified hydrological connections between restored channels and the main river are probably the best solution.

Reconnection of lentic ecosystems with the river can bring quick results with respect to the condition of habitats, but benthic macroinvertebrates may react much more slowly, as this response depends on the colonization potential of the whole river system. Additionally, in decisions regarding restoration of hydrological connectivity its effect on threatened and/ or invasive species should be considered. On the whole, however, the presented results indicate, as the main object of conservation measures, rejuvenation of oxbow lakes by reestablishing their connection with the river. In densely populated lowlands of Central Europe, such information can help improve conservation efforts and lead to success both in improving floodplain morphology and increasing faunal diversity of the areas subjected to restoration. EU Biodiversity Strategy 2020 recognizes the need to include ecosystem services in land use planning, nature protection and conservation. Inclusion of such activities in wetland restoration projects is a new area of research, and the present study contributes to its development. Our results allow only preliminary recommendations and further research is needed. Considering the time scale of the processes occurring in river-floodplain ecosystems, restoration projects require continued studies, and their monitoring should always focus on the long-term effects.

Acknowledgments This study was supported financially by the National Science Centre, grant no. NN305 143240. We thank Szymon Kobus and Paweł Burandt (Dept. of Land Reclamation and Environmental Management, University of Warmia and Mazury) for their help in hydrological studies and Łukasz Maksymowski and Natalia Jarząb (Dept. of Ecology, Pomeranian University in Słupsk) for their help in collecting and preparation of biological material. We thank the anonymous reviewers for their insightful and helpful comments.

Open Access This article is distributed under the terms of the Creative Commons Attribution 4.0 International License (http:// creativecommons.org/licenses/by/4.0/), which permits unrestricted use, distribution, and reproduction in any medium, provided you give appropriate credit to the original author(s) and the source, provide a link to the Creative Commons license, and indicate if changes were made.

\section{References}

APHA, 1989. Standard Methods for the Examination of Water and Wastewater, 17th ed. American Public Health Association (APHA), Washington.

Aspetsberger, F., F. Huber, S. Kargl, B. Scharinger, P. Peduzzi $\&$ T. Hein, 2002. Particulate organic matter dynamics in a river floodplain system: impact of hydrological connectivity. Archiv für Hydrobiologie 156: 23-42. 
Birk, S., W. Bonne, A. Borja, S. Brucet, A. Courrat, S. Poikane, A. G. Solimini, W. van de Bund, N. Zampoukas \& D. Hering, 2012. Three hundred ways to assess Europe's surface waters: an almost complete overview of biological methods to implement the Water Framework Directive. Ecological Indicator 18: 31-41.

Benke, A. C., I. Chaubey, G. M. Ward \& E. L. Dunn, 2000. Flood pulse dynamics of an unregulated river floodplain in the Southeastern US coastal plain. Ecology 81: 2730-2741.

Breithaupt, S. \& T. Khangaonkar, 2011. Effects of wetland restoration on floodplain hydrodynamics under extreme flooding conditions. Ecological Restoration 29: 161-172.

Carlson, R. E., 1977. A trophic state index for lakes. Limnology and Oceanography 22(2): 361-369.

Carlson, R. E. \& J. Simpson, 1996. A Coordinator's Guide to Volunteer Lake. Monitoring Methods. North American Lake Management Society: 96 pp.

Castella, E., O. B. Eguin, A.-L. Besacier-Monbertrand, D. H. Peter, N. Lamoroux, H. Mayor Siméant, D. McCrae, J.M. Olivier \& A. Paillex, 2015. Realised and predicted changes in the invertebrate benthos after restoration of connectivity to the floodplain of a large river. Freshwater Biology 60: 1131-1146.

Cooper, C. M., S. I. I. I. Testa \& F. D. Jr Shields, 2000. Stream restoration: response of benthos to engineered stable riffle/ pool habitat. Verhandlungen Internationale Vereinigung für theoretische und angewandte. Limnologie 27: 1520-1527.

Čížková, H., J. Květ, F. A. Comin, R. Laiho, J. Pokorny \& D. Pithart, 2013. Actual state of European wetlands and their possible future in the context of global climate change. Aquatic Sciences 75: 3-26.

Dolédec, S., E. Castella, M. Forcellini, J. M. Olivier, A. Paillex \& P. Sagnes, 2015. The generality of changes in the trait composition of fish and invertebrate communities after flow restoration in a large river (French Rhône). Freshwater Biology 60: 1147-1161.

Dynesius, M. \& C. Nilson, 1994. Fragmentation and flow regulation in the northern third of the world. Science 266 : $753-762$.

Friberg, N., B. Kronvang, H. O. Hansen \& L. M. Svendsen, 1998. Long-term, habitat-specific response of a macroinvertebrate community to river restoration. Aquatic Conservation 8: 87-99.

Gallardo, B., M. Garcia, Á. CabezasGonzález, E. González, M. C. Ciancarelli \& F. A. Comin, 2008. Macroinvertebrate patterns along environmental gradients and hydrological connectivity within a regulated river-floodplain. Aquatic Science 70: 248-258.

Gallardo, B., C. Español \& F. A. Comin, 2012. Aquatic metabolism short-term response to the flood pulse in a Mediterranean floodplain. Hydrobiologia 693: 251-264.

Gallardo, B., S. Dolédec, A. Paillex, D. B. Arscott, F. Sheldon, F. Zilli, S. Mérigoux, E. Castella \& F. A. Comín, 2014. Response of benthic macroinvertebrates to gradients in hydrological connectivity: a comparison of temperate, subtropical, Mediterranean and semiarid river floodplains. Freshwater Biology 59: 630-648.

Glińska-Lewczuk, K. \& P. Burandt, 2011. Effect of river straightening on the hydrochemical properties of floodplain lakes: observations from the Łyna and Drwęca Rivers, N Poland. Ecological Engineering 37: 786-795.
Grosholz, E. \& E. Gallo, 2006. The influence of flood cycle and fish predation on invertebrate production on a restored California floodplain. Hydrobiologia 568: 91-109.

Hammer, Ř., D. A. T. Harper \& P. D. Ryan, 2001. PAST: paleontological statistics software package for education and data analysis. Palaeontologia Electronica 4(1): 9.

Hildrew, A. G. \& P. S. Giller, 1994. Patchiness, species interactions and disturbance in the stream benthos. In Giller, P. S., A. G. Hildrew, D. G. Raffaelli (eds), Aquatic EcologyScale, Pattern and Process. Proceedings of the 34th Symposium of the British Ecological Society University College, Cork. Blackwell Scientific Publications, Oxford.

Jansson, R., H. Backx, A. J. Boulton, M. Dixon, D. Dudgeon, F. Hughes, K. Nakamura, E. Stanley, \& K. Tockner, 2005. Stating mechanisms and refining criteria for ecologically successful river restoration: a comment on Palmer et al. (2005). Journal of Applied Ecology 42: 218-222.

King, S. L., R. R. Sharitz, J. W. Groninger \& L. L. Battaglia, 2009. The ecology, restoration, and management of southeastern floodplain ecosystems: a synthesis. Wetland 29: 624-634.

Krebs, C. J., 1999. Ecological Methodology. Addison Wesley Longman, Menlo Park.

Lamouroux, N., J. A. Gore, F. Lepori \& B. Statzner, 2015. The ecological restoration of large rivers needs science based, predictive tools meeting public expectations: an overview of the Rhône project. Freshwater Biology 60: 1069-1084.

Lepori, F., D. Palm, E. Brännäs \& B. Malmqvist, 2005. Does restoration of structural heterogeneity in streams enhance fish and macroinvertebrate diversity? Ecological Applications 15: 2060-2071.

Lepš, J. \& P. Šmilauer, 2003. Multivariate Analysis of Ecological Data using CANOCO. Cambridge University Press, Cambridge.

Mandaville, S. M., 2002. Benthic Macroinvertebrates in Freshwaters-taxa Tolerance Values, Metrics, and Protocols. Soil \& Water Conservation Society of Metro Halifax, Nova Scotia.

Martinovic-Vitanovic, V., S. Ostojic, N. Popovic, M. Rakovic \& V. Kalafatic, 2013. Limnological study of serbian oxbow shaped lake Srebrno, with special emphasis on the benthic community composition and structure. Ekologia (Bratislava) 32: 66-86.

Matthaei, C. D., D. Werthmüller \& A. Frutiger, 1997. Invertebrate recovery from a bed-moving spate: the role of drift versus movement inside or over the substratum. Archiv für Hydrobiolgie 140: 221-235.

Obolewski, K., 2008. Rozmieszczenie i struktura makrozoobentosu w zbiorniku Krzynia na terenie Parku Krajobrazowego "Dolina Słupi". Parki Narodowe i Rezerwaty Przyrody 27: 81-97.

Obolewski, K., 2011a. Composition and density of plant-associated invertebrates in relation to environmental gradients and hydrological connectivity of wetlands. Oceanological \& Hydrobiological Studies 40: 52-63.

Obolewski, K., 2011b. Macrozoobenthos patterns along environmental gradients and hydrological connectivity of oxbow lakes. Ecological Engineering 37: 796-805.

Obolewski, K., K. Glińska-Lewczuk, A. Strzelczak \& P. Burandt, 2014a. Effects of a floodplain lake restoration on macroinvertebrate assemblages - a case study of the 
lowland river (the Słupia River, N Poland). Polish Journal of Ecology 63: 557-573.

Obolewski, K., K. Glińska-Lewczuk \& A. Strzelczak, 2014b. The use of macrozoobenthos metrics in the assessment of ecological status of floodplain lakes. Journal of Freshwater Ecology 29(2): 225-242.

Paillex, A., S. Dolédec, E. Castella \& S. Mérigoux, 2009. Large river floodplain restoration: predicting species richness and trait responses to the restoration of hydrological connectivity. Journal of Applied Ecology 46: 250-258.

Paillex, A., S. Dolédec, E. Castella, S. Mérigoux \& D. C. Aldridge, 2013. Functional diversity in a large river floodplain: anticipating the response of native and alien macroinvertebrates to the restoration of hydrological connectivity. Journal of Applied Ecology 50: 97-106.

Paillex, A., E. Castella, P. S. E. zu Ermgassen \& D. C. Aldridge, 2015. Testing predictions of changes in alien and native macroinvertebrate communities and their interaction after the restoration of a large river floodplain (French Rhône). Freshwater Biology 60: 1162-1175.

Parkyn, S. M., R. J. Davies-Colley, N. J. Halliday, K. J. Costley \& G. F. Croker, 2003. Planted riparian buffer zones in New Zealand: do they live up to expectations? Restoration Ecology 11: 436-447.

Pedersen, M. L., N. Friberg, J. Skriver, A. Baattrup-Pedersen \& S. E. Larsen, 2007. Restoration of Skjern River and its valley: short-term effects on river habitats, macrophytes and macroinvertebrates. Ecological Engineering 30: $145-156$.

Pielou, E. C., 1966. The measurement of diversity in different types of biological collections. Journal of Theoretical Biology 13: 131-144.

Reckendorfer, W., 2004. Effects of the hydrological connectivity between the main channel and it's floodplain on benthic invertebrates. Abhandlungen der ZoologischBotanischen Gesellschaft in Österreich 34: 77-98.

Reese, E. G. \& D. P. Batzer, 2007. Do invertebrate communities in floodplains change predictably along a river's length? Freshwater Biology 52: 226-239.
Roni, P., T. Bennett, S. Morley, G. R. Pess, K. Hanson, D. van Dyke \& P. Olmstead, 2006. Rehabilitation of bedrock stream channels: the effects of boulder weir placement on aquatic habitat and biota. River Research and Applications 22: 967-980.

Sartori, L., S. Canobbio, R. Cabrini, R. Fornaroli \& V. Mezzanotte, 2015. Macroinvertebrate assemblages and biodiversity levels: ecological role of constructed wetlands and artificial ponds in a natural park. Journal of Limnology 74 : 335-345.

Schiemer, F., 1999. Conservation of biodiversity in floodplain rivers. Large rivers, 11. Archiv für Hydrobiologie 115: 423-438.

ter Braak, C. J. F. \& P. Śmilauer, 2002. CANOCO Reference manual and CanoDraw for Windows User's guide: Software for Canonical Community Ordination (version 4.5) Micro-computer Power (Ithaca, NY, USA): 500 pp.

Turoboyski, L., 1979. Technical Hydrobiology. PWN Press, Warsaw.

Ward, J. V., K. Tockner \& F. Schiemer, 1999. Biodiversity of floodplain river ecosystems: ecotones and connectivity. Regulated Rivers: Research and Management 15: 125-139.

Ward, J. V., K. Tockner, D. B. Arscott \& C. Claret, 2002. Riverine landscape diversity. Freshwater Biology 47: 517-539.

Wilk-Woźniak, E., S. Ligęza \& E. Shubert, 2014. Effect of water quality on phytoplankton structure in oxbow lakes under anthropogenic and non-anthropogenic impacts. Clean - Soil, Air, Water 42(4): 421-427.

Wright, R. G., M. P. Murray \& T. Merrill, 1998. Ecoregions as a level of ecological analysis. Biological Conservation 86 : 207-213.

Wright, J. F., D. W. Sutcliffe \& M. T. Furse (eds), 2000. Assessing the biological quality of waters, RIV-PACS and other techniques. Freshwater Biological Association, Ambleside. 